\title{
Effects of Combined Zr and Mn Additions on Dispersoid Formation and Recrystallisation Behaviour of AA2198 Sheet
}

\author{
Dimitrios Tsivoulas ${ }^{1, a}$, Philip Prangnell ${ }^{1, b}$, Christophe Sigli ${ }^{2, c}$, Bernard Bès ${ }^{2, d}$ \\ ${ }^{1}$ Materials Science Centre, School of Materials, The University of Manchester, Grosvenor Street, \\ Manchester, M1 7HS, UK \\ ${ }^{2}$ Alcan Centre de Recherches de Voreppe, B.P. 27, 725 rue Aristides Bergès, 38340 Voreppe, \\ France \\ adtsivoulas@yahoo.com, ${ }^{b}$ philip.prangnell@manchester.ac.uk, ${ }^{c}$ christophe.sigli@alcan.com, \\ dbernard.bes@alcan.com
}

Keywords: recrystallisation; dispersoids; Al3Zr; homogenisation; microsegregation;

\begin{abstract}
The present paper focuses on the influence of combined additions of $\mathrm{Zr}$ and $\mathrm{Mn}$ on the recrystallisation resistance of aluminium alloy 2198 sheet. Dual additions of these dispersoid forming elements have previously been reported to be beneficial for reducing recrystallisation during solution treatment, as they exhibit opposing microsegregation partitioning on solidification. Contrary to expectation, it was found that the addition of $\mathrm{Mn}$, to a standard $\mathrm{Zr}$-containing 2198 sheet material, reduced recrystallisation resistance. The reasons for this behaviour are explored by analysis of the morphology, size, chemistry, and distribution of the dispersoid families formed, as a function of the $\mathrm{Mn}$ and $\mathrm{Zr}$ level, traced back to the homogenisation stage.
\end{abstract}

\section{Introduction}

It has been claimed that combined additions of $\mathrm{Zr}$ and $\mathrm{Mn}$ dispersoid forming elements in aluminum alloys offer a range of advantages, including improved mechanical properties [1] and better high strain rate superplasticity [2]. However, the main benefits expected from the coexistence of $\mathrm{Al}_{3} \mathrm{Zr}$ and $\mathrm{Al}_{\mathrm{x}} \mathrm{Cu}_{\mathrm{y}} \mathrm{Mn}_{\mathrm{z}}$ precipitate families are related to an increased recrystallisation resistance from the promotion of a more uniform dispersoid distribution [3]. In principle this should minimise the level of partial recrystallisation that would otherwise typically occur within regions of low dispersoid density. For example, in alloys containing only $\mathrm{Zr}$ a dispersoid free zone exists near the grain boundaries prior to rolling [4]. This more uniform dispersoid distribution results from opposing microsegregation partitioning during solidification [5], with $\mathrm{Zr}$ segregating inversely to the dendrite cores and $\mathrm{Mn}$ normally to the boundaries, leading to a more homogeneous concentration of dispersoid forming elements in solution prior to homogenisation.

Unfortunately, there is still not a consensus on results reported for the effect of dual $\mathrm{Mn}$ and $\mathrm{Zr}$ additions on the mechanical behaviour of aerospace Al-alloys. While an increase in UTS and $\sigma_{\mathrm{y}}$ have been observed [1,6], the ductility has been found to increase [2], decrease [7], or remain unchanged, on addition of Mn [6]. Furthermore, Cho and Bès [8] have reported that in a 2139 alloy all the mechanical properties, and especially fracture toughness, diminished compared to when only $\mathrm{Mn}$ additions were used. Results on recrystallisation resistance are also contradictory, with observations showing improvements [9] as well as an increase in the level of recrystallisation [10]. At a microstructural level, a number of interactions between $\mathrm{Zr}$ and $\mathrm{Mn}$ have been noted, but not clearly related to recrystallisation resistance. For example, $\mathrm{Mn}$ and $\mathrm{Zr}$ have been found to dissolve within $\mathrm{Al}_{3} \mathrm{Cr}$ dispersoids and $\mathrm{Zr}$ and $\mathrm{Cr}$ have been detected in the $\mathrm{Al}_{6} \mathrm{Mn}$ phase in an $\mathrm{Al}-\mathrm{Mg}-\mathrm{Mn}$ alloy containing $\mathrm{Zr}$ and $\mathrm{Cr}$ [11]. It has also been claimed that $\mathrm{Mn}$ in solid solution can increase the volume fraction of the $\mathrm{Al}_{3} \mathrm{Zr}$ or $\mathrm{Al}_{3}(\mathrm{Zr}, \mathrm{Sc})$ dispersoids and the presence of $\mathrm{Zr}$ slows down the precipitation kinetics of Mn dispersoids [12]. On the other hand, Johansen et al. [13] noted that there was little interaction and the distribution of Mn dispersoids was insignificantly affected by the 
addition of Zr. Other data has shown that the solubility of $\mathrm{Mn}$ is not greatly affected by the presence of $\mathrm{Zr}$, with only a marginal decrease reported [12].

To address some of these issues, this paper will focus on the influence of combined $\mathrm{Zr}$ and $\mathrm{Mn}$ additions on the recrystallisation resistance of 2198 sheet. Contrary to expectation, it was found that the addition of $\mathrm{Mn}$ to a standard $\mathrm{Zr}$-containing material reduced recrystallisation resistance. The reasons for this behaviour are explored, by analysis of the morphology, size, chemistry, and distribution of the dispersoid families formed, as a function of the $\mathrm{Mn}$ and $\mathrm{Zr}$ level, traced back to the homogenization stage.

\section{Experimental}

The materials used were based on a DC cast 2198 alloy, hot rolled to $6 \mathrm{~mm}$ sheet (supplied in T351 and $\mathrm{F}$ tempers) with four different $\mathrm{Zr}$ and $\mathrm{Mn}$ contents; $0.1 \mathrm{Zr}$ (conventional), $0.1 \mathrm{Zr}-0.3 \mathrm{Mn}, 0.05 \mathrm{Zr}$ $0.3 \mathrm{Mn}, 0.4 \mathrm{Mn}$. A 2050 cast slice of similar base composition, containing both $\mathrm{Mn}$ and $\mathrm{Zr}$, was also analysed to investigate how the dispersoids were distributed prior to rolling. The compositions of both alloys are given in Table 1. Annealing and homogenisation treatments were carried out in an air circulating furnace followed by quenching in water. Grain structures were characterised by EBSD in the RD-ND plane using an FEI-Sirion FEG-SEM with a step size of $1 \mu \mathrm{m}$. Crystallographic textures were determined from large area EBSD maps. TEM was employed to quantify the dispersoid distributions and analyse individual particles. TEM samples were spark-cut and thinned to perforation by a twin-jet electropolisher, before analysis in a FEI-Tecnai F30 microscope at $300 \mathrm{kV}$.

\begin{tabular}{||c|c|c|c|c|c|c|c|c|c|c||}
\hline \hline Alloy & $\mathrm{Cu}$ & $\mathrm{Li}$ & $\mathrm{Mg}$ & $\mathrm{Ag}$ & $\mathrm{Zr}$ & $\mathrm{Mn}$ & $\mathrm{Zn}$ & $\mathrm{Fe}$ & $\mathrm{Si}$ & $\mathrm{Ti}$ \\
\hline 2198 & $2.90-3.50$ & $0.80-1.10$ & $0.25-0.80$ & $0.10-0.50$ & varied & varied & 0.02 & 0.05 & 0.03 & 0.02 \\
\hline 2050 & $3.20-3.90$ & $0.70-1.30$ & $0.20-0.60$ & $0.20-0.70$ & $0.06-0.14$ & $0.20-0.50$ & 0.25 & 0.10 & 0.08 & 0.10 \\
\hline \hline
\end{tabular}

Table 1: AA compositions of the alloys used [wt $\%$ ] (Al is balanced)

\section{Results and Discussion}

Recrystallisation Resistance. EBSD measurements were carried out on the four sheet alloys in the F (hot rolled) temper and following solution treatment (T351) to quantify their levels of texture and recrystallisation respectively, relative to their dispersoid content (see below). Example maps and the statistical data obtained are presented in Figs. $1 \& 2$. All the as-deformed alloys had similar fibrous grain structures (not shown) and textures. The deformation textures were typical of those seen in similar Al-alloys [14], S $\{123\}<634>$ being the strongest component on the $\beta$ fibre, followed by Brass $\{011\}<211>$ and lower intensities of Copper $\{112\}<111>$, with traces of Cube $\{001\}<100>$ and Goss $\{011\}<100>$. The deformation textures showed no significant dependence on the $\mathrm{Zr}$ or Mn content (Fig. 2a).
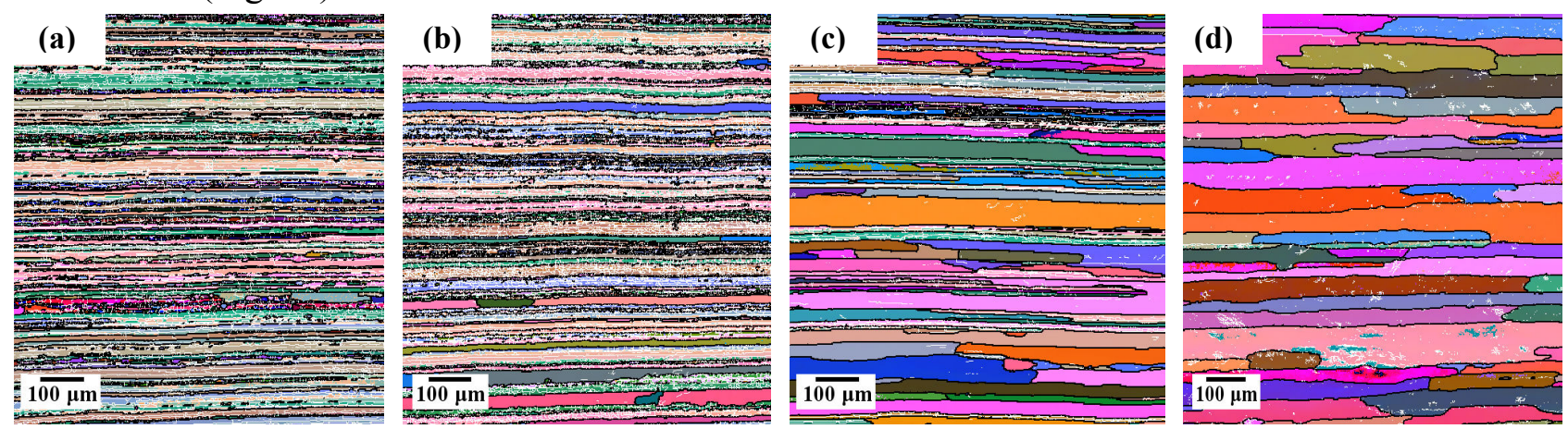

Fig. 1: EBSD maps from the mid sheet thickness of the $2198-\mathrm{T} 351$ alloys containing: a) $0.1 \mathrm{Zr}, \mathrm{b}) 0.1 \mathrm{Zr}-0.3 \mathrm{Mn}$, c) $0.05 \mathrm{Zr}-0.3 \mathrm{Mn}$, d) $0.4 \mathrm{Mn}$.

From comparison of the EBSD maps in Fig. 1, following solution treatment, it is evident that recrystallisation resistance reduced dramatically with lower $\mathrm{Zr}$ levels, despite the corresponding 
increase in Mn content. The measured recrystallised volume fractions, presented in Fig. $2 \mathrm{~b}$, show the same trend near the sheet surface, but with a higher general level of recrystallisation. Indeed, the material only containing $\mathrm{Mn}(0.4 \%)$ was fully recrystallised at the surface following solution treatment, whereas in the standard alloy with just $\mathrm{Zr}$ no recrystallisation could be detected. At the sheet centre there is less stored energy following hot rolling but the $0.4 \% \mathrm{Mn}$ alloy was again fully recrystallised. This behaviour is not unexpected, as the plate morphology $\mathrm{Al}_{\mathrm{x}} \mathrm{Cu}_{\mathrm{y}} \mathrm{Mn}_{\mathrm{z}}$ dispersoids are nearly an order of magnitude coarser $(\sim 100-300 \mathrm{~nm})$ than the finer spherical coherent $\beta, \mathrm{Al}_{3} \mathrm{Zr}$ phase after homogenization ( 20-50 nm) (Fig. 3). The $\mathrm{Al}_{\mathrm{x}} \mathrm{Cu}_{\mathrm{y}} \mathrm{Mn}_{\mathrm{z}}$ dispersoids consequently provide a far lower Zener drag on boundary mobility, which is dependent on the dispersoid particle surface area interacting with the boundary plane [3]. More surprisingly, the $0.1 \mathrm{Zr}-0.3 \mathrm{Mn}$ alloy (Fig. 1b) that contained the same $\mathrm{Zr}$ level as the $0.1 \mathrm{Zr}$ standard 2198 alloy (Fig. 1a), also exhibited a higher level of recrystallisation when $0.3 \%$ of Mn was added, which might be expected to lead to a greater dispersoid density and a more uniform distribution. This was particularly noticeable at the sheet surface where the volume fraction of recrystallisation increased from $\sim$ zero, without Mn, to $\sim 40 \%$ in the $0.1 \mathrm{Zr}-0.3 \mathrm{Mn}$ alloy. Equivalent circular diameter (ECD) grain size measurements showed similar trends to the level of recrystallisation, with the fully recrystallised $0.4 \mathrm{Mn}$ alloy having a grain size eight times larger than the largely unrecrystallised $0.1 \mathrm{Zr}$ alloy.
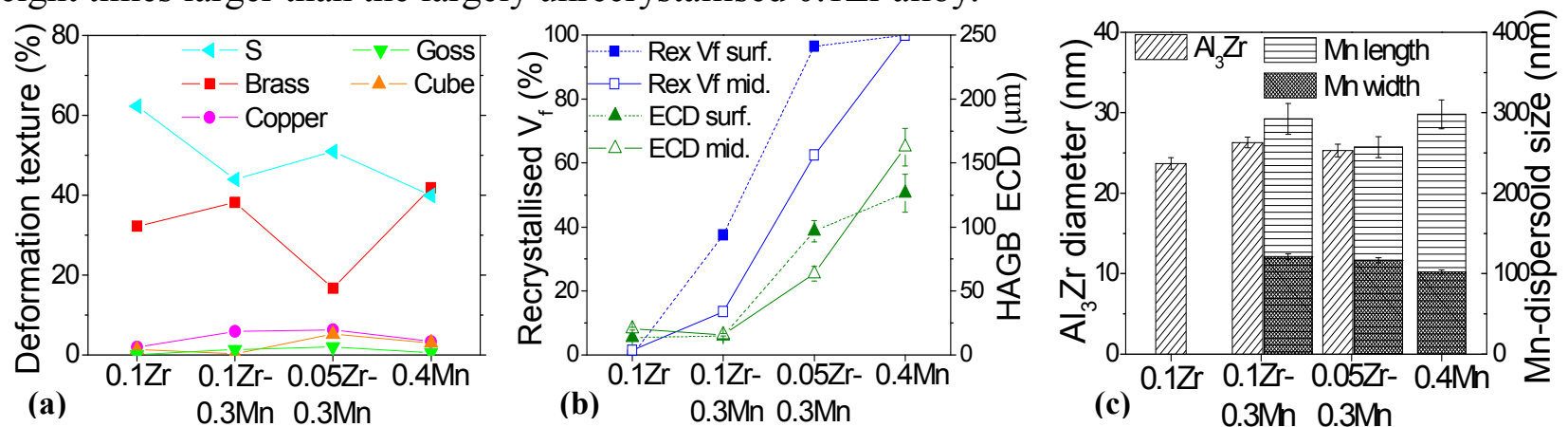

Fig. 2: a) Effect of dispersoid content on the volume fractions of the main deformation texture components in $\mathrm{F}$ temper; b) Recrystallised volume fraction and grain size versus composition, measured at the surface and mid-thickness of the sheet in $\mathrm{T} 351$ and $\mathrm{c}$ ) the $\mathrm{Al}_{3} \mathrm{Zr}$ and $\mathrm{Al}_{\mathrm{x}} \mathrm{Cu}_{\mathrm{y}} \mathrm{Mn}_{\mathrm{z}}$ average dispersoid size measured in the $\mathrm{T} 351$ temper.
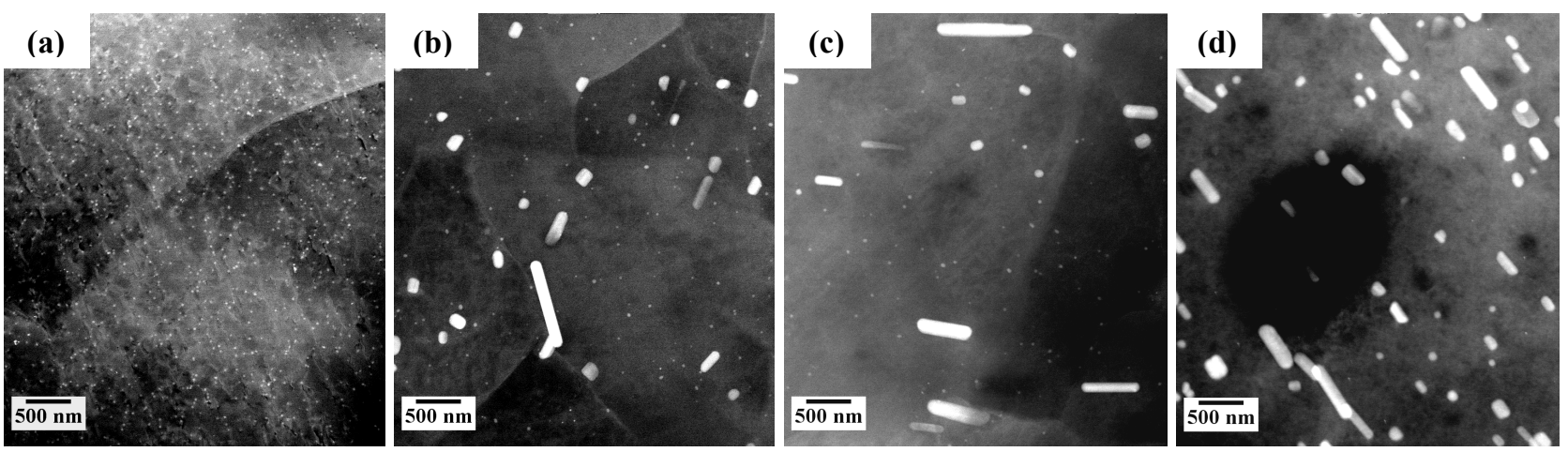

Fig. 3: STEM HAADF images of dispersoid distributions for alloys in T351 condition; a) $0.1 \mathrm{Zr}, \mathrm{b}) 0.1 \mathrm{Zr}-0.3 \mathrm{Mn}$, c) $0.05 \mathrm{Zr}-0.3 \mathrm{Mn}$, d) $0.4 \mathrm{Mn}$.

Influence of Dispersoid Distributions. Examples of STEM HAADF images of the dispersoid distributions in the four alloys can be seen in Fig. 3, all taken with a similar foil thickness. The large difference in scale of the two families of dispersoids is readily apparent and the average sizes in each alloy are given in Fig. 2c. It is evident that if they had an identical volume fraction, the Zener pinning pressure (proportional to $\mathrm{V}_{\mathrm{f}} / \mathrm{d}$ [3]) would be a factor of $\sim 10$ times lower for the $\mathrm{Al}_{\mathrm{x}} \mathrm{Cu}_{\mathrm{y}} \mathrm{Mn}_{\mathrm{z}}$ dispersoids than that for the $\mathrm{Al}_{3} \mathrm{Zr}$ phase. In Fig. 2c it is noticeable that the size of the $\mathrm{Al}_{3} \mathrm{Zr}$ precipitates appear to be slightly larger in both the $0.1 \mathrm{Zr}-0.3 \mathrm{Mn}$ and $0.05 \mathrm{Zr}-0.3 \mathrm{Mn}$ alloys than in the conventional $0.1 \mathrm{Zr} 2198$ alloy. Although the difference in the $\mathrm{Al}_{3} \mathrm{Zr}$ size is not great, previous work [4] has shown that it is consistent with a lower supersaturation for nucleation. In a dilute alloy, even a small decrease in solute in solution has a large effect on the nucleation rate, allowing particles to 
grow larger before impingement of their solute depletion fields during precipitation [4]. Furthermore, although care is required because of the sensitivity to local variability, examination of Figs. $3 \mathrm{a}$ and $3 \mathrm{~b}$ suggests there is a lower number density of $\mathrm{Al}_{3} \mathrm{Zr}$ dispersoids in the $0.1 \mathrm{Zr}-0.3 \mathrm{Mn}$ sheet than in the $0.1 \mathrm{Zr}$ alloy, despite the identical $\mathrm{Zr}$ content in both of them. In fact, measured values of number density for these two alloys are approximately 67 and $132 \mu \mathrm{m}^{-3}$ respectively.

Previously, research has indicated that dual $\mathrm{Mn}$ and $\mathrm{Zr}$ additions would be beneficial in inhibiting partial recrystallisation in thick plate [15] because this results in a more uniform dispersoid distribution. In contrast, in thin sheet the higher reduction ratio means that the dispersoid free zones found near grain boundaries, in alloys containing only $\mathrm{Zr}$, have less influence on recrystallisation. For example, the $\mathrm{Al}_{3} \mathrm{Zr}$ dispersoid free zone near grain boundaries in $\mathrm{DC}$ cast rolling billets have been measured to be $\sim 10 \mu \mathrm{m}$ [4]. In thick plate, partial recrystallisation initiates in these regions and progresses until the dispersoid density increases sufficiently towards the centre of the original grains to prevent boundary migration [16]. In a $6 \mathrm{~mm}$ sheet the cast grain structure will be far more compressed. For example, the $\mathrm{Al}_{3} \mathrm{Zr}$ dispersoid free zones in the casting will reduce to $<0.2 \mu \mathrm{m}$ in width, which is smaller than the subgrain size and the original inhomogeneous distribution of $\mathrm{Zr}$ in the casting will have a low impact on recrystallisation, as it is effectively smeared out at high rolling reductions. This is apparent from the fact that the $0.1 \mathrm{Zr} 6 \mathrm{~mm}$ sheet showed low levels of recrystallisation compared to the $10-15 \%$ typically seen in a hot rolled plate [16]. Because of the greater reduction ratio, higher stored energy in thin sheet and the large difference in pinning pressure of the two families of dispersoids, it is evident that recrystallisation inhibition is dominated more by the average density of the $\mathrm{Al}_{3} \mathrm{Zr}$ phase. Therefore, in a sheet product the observed reduction in density of Zr-containing dispersoids, when $\mathrm{Mn}$ is added, results in a detrimental increase in the level of recrystallisation. The reasons why Mn additions lead to a reduction in the $\mathrm{Al}_{3} \mathrm{Zr}$ dispersoid density are explored below.
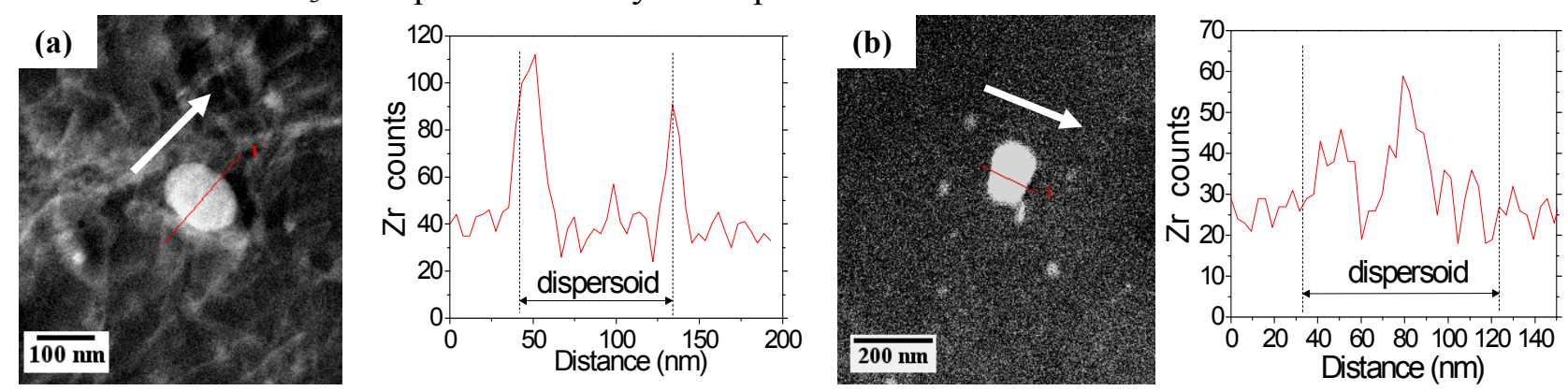

Fig. 4: Example EDX line scans showing the $\mathrm{Zr}$ counts detected across two $\mathrm{Al}_{\mathrm{x}} \mathrm{Cu}_{\mathrm{y}} \mathrm{Mn}_{\mathrm{z}}$ dispersoids (a) \& (b) in the $0.1 \mathrm{Zr}-0.3 \mathrm{Mn}$ T351 alloy; the arrows show the scan direction.

Dispersoid Compositions. A possible reason for the reduction of the $\mathrm{Al}_{3} \mathrm{Zr}$ number density is the dissolution of $\mathrm{Zr}$ within the Mn-containing dispersoids, reducing the $\mathrm{Zr}$ available for precipitation of $\mathrm{Al}_{3} \mathrm{Zr}$ dispersoids. EDX line scans performed in STEM mode showed that small amounts of $\mathrm{Zr}$ were dissolved within certain types of $\mathrm{Al}_{\mathrm{x}} \mathrm{Cu}_{\mathrm{y}} \mathrm{Mn}_{\mathrm{z}}$ dispersoids in the $0.1 \mathrm{Zr}-0.3 \mathrm{Mn} 2198$ sheet material. Fig. 4a shows a small, elliptical-shaped Mn-rich dispersoid where high $\mathrm{Zr}$ concentrations were detected at the particle/matrix interface. The high $\mathrm{Zr}$ concentration can also be seen in the image from $\mathrm{Z}$ contrast, in the form of a narrow bright shell surrounding the particle. Another example is given in Fig. 4b. In this case an increase in $\mathrm{Zr}$ concentration is seen in the centre of the particle. $\mathrm{Zr}$ was detected in several elliptical-shaped, low aspect ratio $\mathrm{Al}_{\mathrm{x}} \mathrm{Cu}_{\mathrm{y}} \mathrm{Mn}_{\mathrm{z}}$ dispersoids, but for other morphologies, such as the high aspect ratio plates, no $\mathrm{Zr}$ was detected. There is thus evidence that $\mathrm{Zr}$ is tied up in specific Mn-containing particles, but not all $\mathrm{Al}_{\mathrm{x}} \mathrm{Cu}_{\mathrm{y}} \mathrm{Mn}_{\mathrm{z}}$ dispersoids.

Dispersoid Distribution after Homogenisation. $\mathrm{Zr}$ and $\mathrm{Mn}$ exhibit a strong tendency to segregate within grains during casting and, because they have low diffusivity in aluminium, their microsegregation patterns remain to a large extent after homogenisation [5]. To better understand the correlation between the composition of the two families of dispersoids and the microsegregation 
developed on solidification, homogenised samples of a 2050 as-cast ingot slice were analysed by SEM and TEM. This alloy was chosen as it had a similar composition and $\mathrm{Zr}$ and $\mathrm{Mn}$ concentration to the $0.1 \mathrm{Zr}-0.3 \mathrm{Mn} 2198$ sheet sample (see Table 1). In Figs. 5a and 6a it can be clearly seen that the $\mathrm{Al}_{\mathrm{x}} \mathrm{Cu}_{\mathrm{y}} \mathrm{Mn}_{\mathrm{z}}$ dispersoid density decreases, while their size and aspect ratio increases, towards the centre of a grain, as a result of $\mathrm{Mn}$ segregation towards the dendrite/grain boundaries. Indeed, at the dendrite core the $\mathrm{Al}_{\mathrm{x}} \mathrm{Cu}_{\mathrm{y}} \mathrm{Mn}_{\mathrm{z}}$ density falls to near zero. An opposite behavior occurs for the $\mathrm{Al}_{3} \mathrm{Zr}$ phase, as exemplified by the work of Robson [4], but has not been shown here due to a lack of space. The segregation behaviour of $\mathrm{Zr}$ and $\mathrm{Mn}$ across a dendrite can be accurately simulated by a previously developed model that couples thermodynamic data with an analysis of solute partitioning and back diffusion (ALCAN Thermodynamic Package Prophase [17]). The predicted dispersoid distribution across a grain following homogenisation is presented in Fig. 5b; it shows that, due to the higher Mn supersaturation near the grain boundary, the nucleation rate of the Mn-dispersoids is much greater than in the grain centre, giving rise to a higher density of particles. The opposite effect takes place in the case of $\mathrm{Zr}$, which has also been modeled by Robson [4].

(a)

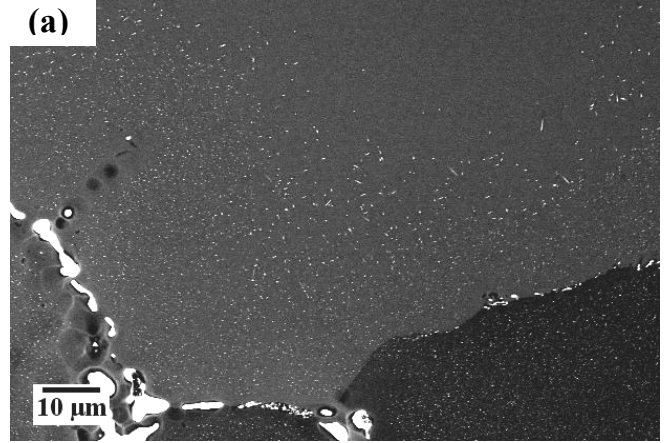

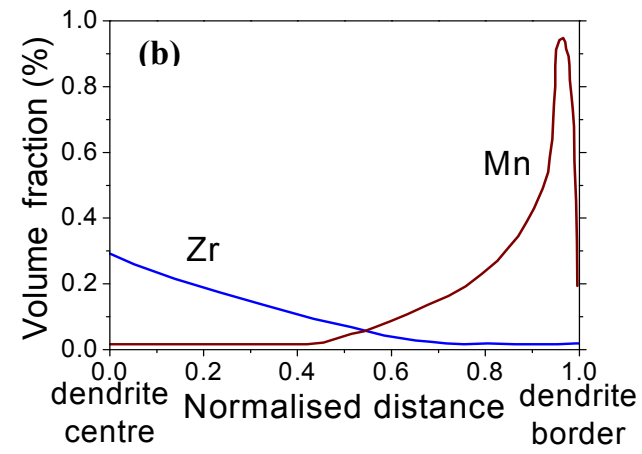

Fig. 5: a) SEM image showing the distribution of $\mathrm{Al}_{\mathrm{x}} \mathrm{Cu}_{\mathrm{y}} \mathrm{Mn}_{\mathrm{z}}$ dispersoids across a dendrite arm, in a 2050 ingot slice after homogenisation and b) the corresponding $\mathrm{Mn}$ - and $\mathrm{Zr}$-dispersoid volume fractions predicted across a dendrite arm by the ALCAN Thermodynamic Package Prophase [17].

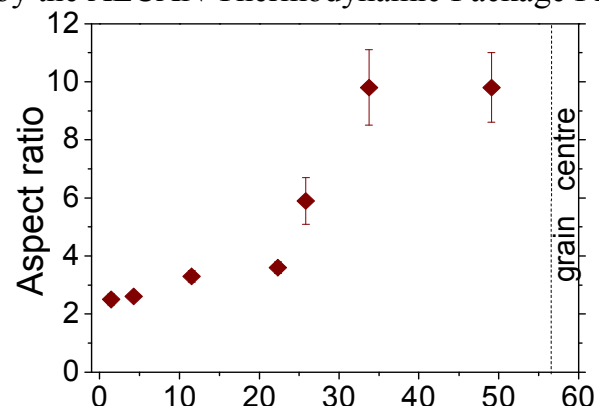

(a)

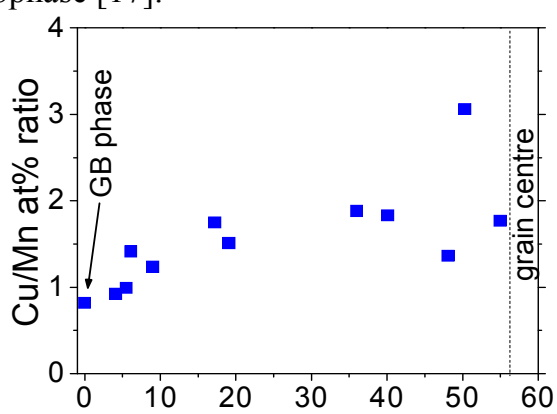

(b) Distance from GB (ì m)

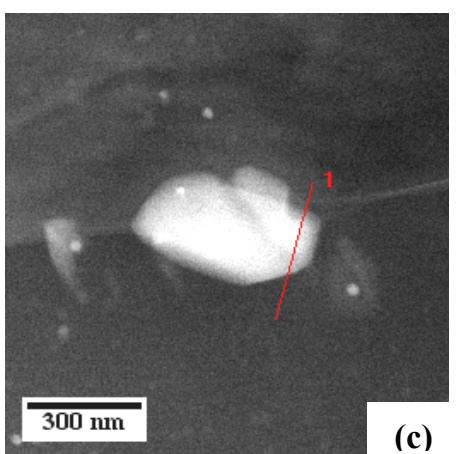

Fig. 6: a) $\mathrm{Al}_{\mathrm{x}} \mathrm{Cu}_{\mathrm{y}} \mathrm{Mn}_{\mathrm{z}}$ dispersoid aspect ratio and b) $\mathrm{Cu}: \mathrm{Mn}$ atomic percent ratio, measured by EDX, across a dendrite arm in the 2050 ingot slice after homogenisation. c) Analysed $\mathrm{Zr}$-containing $\mathrm{Al}_{\mathrm{x}} \mathrm{Cu}_{\mathrm{y}} \mathrm{Mn}_{\mathrm{z}}$ particle on a grain boundary.

STEM mode EDX measurements were performed on selected particles across a grain from the boundary to the centre and the data is presented in Fig. 6. In Fig. $6 \mathrm{~b}$ the ratio of $\mathrm{Cu}: \mathrm{Mn}$ is shown within the $\mathrm{Al}_{\mathrm{x}} \mathrm{Cu}_{\mathrm{y}} \mathrm{Mn}_{\mathrm{z}}$ dispersoids across the grain. It can be seen that the $\mathrm{Cu}: \mathrm{Mn}$ ratio content is lower near the boundary and increases from around 1 to a plateau of $\sim 1.8$. A Cu:Mn ratio of 1.8 is higher than the normally reported stoichiometry for the $\mathrm{Al}_{20} \mathrm{Cu}_{2} \mathrm{Mn}_{3}$ phase [18], due to the high level of $\mathrm{Cu}$ in the matrix which is inevitably detected during the EDX scan. Although Zr is difficult to detect because of its low concentration, during this analysis a statistically higher level of $\mathrm{Zr}$ was not found in any of the Mn-rich dispersoids analysed within a grain. In contrast, Zr was detected within larger lower aspect ratio $\mathrm{Mn}$ - and $\mathrm{Cu}$-containing particles located on grain boundaries, an example of which is shown in Fig. 6c. The crystallography of these particles has not yet been determined. However, it is likely they are similar to the low aspect ratio $\mathrm{Cu}$ - and $\mathrm{Mn}$-rich particles found to contain $\mathrm{Zr}$ in the 2198 rolled sheet. Furthermore, the implication from their location is that they form on solidification and tie up $\mathrm{Zr}$ that would otherwise be available for dispersoid formation. 


\section{Conclusions}

An investigation of the effect of combined additions of $\mathrm{Zr}$ and $\mathrm{Mn}$ on recrystallisation resistance in 2198 sheet has shown that $\mathrm{Mn}$ increases the tendency for recrystallization, but has little influence on the deformation texture. Due to the higher reduction ratio, Mn does not lead to the benefits seen in thick hot rolled plate materials where it helps to inhibit partial recrystallisation near grain boundaries by compensating for the low levels of $\mathrm{Al}_{3} \mathrm{Zr}$ dispersoids, arising from inverse $\mathrm{Zr}$ segregation in the original cast billet. When a more uniform $\mathrm{Al}_{3} \mathrm{Zr}$ dispersoid density is obtained, at higher rolling strains, the additional average pinning pressure from the $\mathrm{Al}_{\mathrm{x}} \mathrm{Cu}_{\mathrm{y}} \mathrm{Mn}_{\mathrm{z}}$ dispersoids is small relative to that provided by the smaller $\mathrm{Zr}$ dispersoids. However, on addition of $\mathrm{Mn}$ to the $\mathrm{Zr}-$ containing 2198 alloy, the size of $\mathrm{Al}_{3} \mathrm{Zr}$ dispersoids was found to increase, while their density decreased, reducing the overall pinning pressure available to resist recrystallisation during solution treatment. The reduction in $\mathrm{Al}_{3} \mathrm{Zr}$ dispersoid density resulting from the addition of $\mathrm{Mn}$ is probably related to a lower $\mathrm{Zr}$ supersaturation during homogenisation. This effect has been tentatively linked to the alloying of $\mathrm{Zr}$ within small Mn-rich particles, predominantly located at the grain boundaries in the homogenised ingot.

\section{Acknowledgements}

The leading author would like to thank LATEST, the University of Manchester EPSRC Light alloys Portfolio Partnership (EP/D029201/1) for funding this project and Alcan CRV for the provision of the materials and partial financial support.

\section{References}

[1] D. S. Chung, C. W. Jea, J. H. Yoon, J. K. Kim: Materials Science Forum Vol. 539-543 (2007), p. 481

[2] S.-W. Lee, J.-W. Yeh: Materials Science and Engineering A Vol. 460-461 (2007), p. 409

[3] E. Nes, N. Ryum, O. Hunderi: Acta Metallurgica Vol. 33 (1985), p. 11

[4] J. D. Robson, P. B. Prangnell: Acta Materialia Vol. 49 (2001), p. 599

[5] Z. Jia, G. Hu, B. Forbord, J. K. Solberg: Materials Science and Engineering A Vol. 444 (2007), p. 284

[6] J. Chang, I. Moon, C. Choi: Metallurgical and Materials Transactions A Vol. 29 (1998), p. 1873

[7] J. L. Ning, D. M. Jiang: Materials Science and Engineering A Vol. 452-453 (2007), p. 552

[8] A. Cho, B. Bès: Materials Science Forum Vol. 519-521 (2006), p. 603

[9] B. Forbord, H. Hallem, K. Marthinsen: Proceedings of the 9th International Conference on Aluminium Alloys, Brisbane, Australia (2004), p. 1179

[10] S. Cheong, H. Weiland: Materials Science Forum Vol. 558-559 (2007), p. 153

[11] R. Kaibyshev, F. Musin, D. R. Lesuer, T. G. Nieh: Materials Science and Engineering A Vol. 342 (2003), p. 169

[12] T. Ohashi, L. Dai, N. Fukatsu: Metallurgical and Materials Transactions A Vol. 17 (1986), p. 799

[13] A. Johansen, Ø. Bauger, J. D. Embury, N. Ryum: Aluminium Vol. 82 (2006), p. 980

[14] A. Cho, Z. Long, B. Lisagor, T. Bales, M. Domack, J. Wagner: Materials Science Forum Vol. 519-521 (2006), p. 1585

[15] T. Warner: Materials Science Forum Vol. 519-521 (2006), p. 1271

[16] J. D. Robson, P. B. Prangnell: Materials Science and Technology Vol. 18 (2002), p. 607

[17] C. Sigli, L. Maenner, C. Sztur, R. Shahani: Aluminium Alloys: Their physical and mechanical properties (ICAA6), Toyohashi, Japan: JILM (1998), p. 87

[18] C. Li, S. C. Wang, Y. Jin, M. Hua, M. Yan: Aluminium Alloys '90. Second International Conference on Aluminium Alloys-Their Physical and Mechanical Properties, Beijing, China (1990), p. 504 